\title{
The Principal's Leadership in Developing Quality of Education
}

\author{
Case Study
}

\author{
Abdul Muin, Murtadho, Haris Supratno
}

Department of Educational Management, Universitas Negeri Surabaya, Indonesia

\begin{abstract}
Quality problems have attracted attention from organizations in the world. Initially, Qualityimprovement start from manufacturing company which spread to the other aspects of service such as banking, insurance, health, government, and education. Evaluation for Quality-improvement is a trend for products and services research. Institute of education must increase its quality which is proven by producing high-quality graduates. This research was conducted in Senior High School 1 Pamekasan and Senior High School 3 Pamekasan. This research has focused on leadership style of the principal to improve the education quality, the strategy of principal to improve the education quality and quality of education which is produced by leadership style and strategy of principal both in Senior High school 1 Pamekasan and Senior High school 3 Pamekasan. This study is quantitative research which studies case and multi-site design. The object of this research is the leadership style and strategy of the principal to increase their school quality. The data was collected by interview, observation, and documentation. Validation data was gotten by source, technical and time triangulation. The Multi-site design was analyzed by individual site and cross-site data. The results of this study showed that the first, the leadership style applied appropriately with the principal principle of necessity is in accordance with the potential resources and increases the capability of principal with an effective leadership style. The second, Implementation of the Integrated Quality Management strategy was used to increase education quality by improving the overall education system by involving the elements of school. The principal has a good relationship with the internal and external school. The third, quality of education produced in the school creates school culture which productive and good quality and builds a mental organization.
\end{abstract}

Keywords - Quality, improvement, institute of education.

\section{INTRODUCTION}

Quality problems have attracted the attention of various organizations in the world. Initially, the quality improvement movement began with manufacturing companies which then spread to various aspects of services such as banking, insurance, health, government, and education [1]. Simply stated, quality is defined as a consistency to meet customer needs and expectations [2], in accordance with expectations [3], and the journey to be superior [4].

Overtime, studies on quality especially the quality of education is still on debate. Therefore, education must find the right approach in developing its institutions to achieve maximum educational goals.

Each educational institution in essence strives to improve the quality of its institutions as evidenced by the output of quality graduates. This has become one of the efforts to develop the quality of education. However, all these efforts will be in vain if the school does not carry out a quality education process and become a culture in the school. Simply stated, culture of quality is considered as a particular type of organizational culture that includes shared values and commitment to build quality [5]. Then the term is adopted in terms of quality and defined as an effort to improve the quality carried out to improve the quality of education that has been arranged previously.

By implementing a culture of quality, the consequence that must be carried out by an educational institution is that quality improvement must be carried out to provide quality education. A school principal is the leader of an educational institution. His role is very influential in achieving the quality of education of the institution he leads. Therefore, the principal must be sensitive to any changes that occur. Both the quality of education and 
May-Jun 2020 /Available online: https://ijels.com/

culture can only be achieved if the principal can play his role well.

A study conducted by [6] found that in improving the quality of education, one of the determining factors was the principal's leadership style. The principal must be aware of the changes that occur and prepare steps for adaptation and improvement. In this matter, reference [7] also stated that the principal has an important role in creating a collaborative environment. Therefore, leadership is an important resource for the education environment in relation to commitment [8], reference [9] defines a Good leader is a leader who involves and considers others and decide a decision humbly.

Based on the description above, researchers found a link between the role of the principal's leadership in building the quality of education. The principal's role is then classified based on the principal's strategy and the principal's leadership style. Principal's leadership is one of the factors influencing his success. Basically, leadership is rooted in ethical and moral teachings, leading, motivating people to achieve success [10]. The character of leadership is encouraging followers to act on specific goals that represent the values and motivations for their wants and needs. More specifically, Principal Leadership is defined as the ability of principals to influence all school resources, both the resources of educators, educational staff, students, and all human resources involved in the education committee to carry out a series of educational activities in accordance with school policies.

\section{THE OBJECTIVE OF STUDY}

This research was conducted in Senior High School 1 Pamekasan and Senior High School 3 Pamekasan. This research focused to investigate on leadership style of the principal to improve the education quality, the strategy of principal to improve the education quality and quality of education which is produced by leadership style and strategy of principal both in Senior High school 1 Pamekasan and Senior High school 3 Pamekasan. The object of this research is the leadership style and strategy of the principal to increase their school quality.

\section{METHODOLOGY}

This research was conducted using a qualitative approach. A qualitative approach is a study conducted on natural object conditions, with characteristics: 1) descriptive, 2) analyze the processes, 3) Pay more attention to processes, and 4) Research is a key instrument. This research uses a case study. Case study (case study) is a study of a "unity of the system". Case studies are used by researchers to find out the actual and in-depth background of cases that do need to be revealed, namely the principal's leadership in building the quality of education in Senior High School 1 Pamekasan and Senior High School 3 Pamekasan.

\subsection{Data Collection Technique}

\subsubsection{Participant Observation}

This observation was carried out to gather data related to the principal's leadership in building the quality of education. With this participant observation, the data obtained will be more complete, actual, and obtained the contextual meaning.

\subsubsection{Deep interview}

Interviews were conducted using free and in-depth interview guidelines regarding the focus of the study. Readiness of researchers and schools in exploring questions and answers is needed. The steps of this are making an interview guide, conducting interviews with students, teachers, principals related to the principal's leadership in building the quality of education. This interview was used to capture data related to the vision of leadership, leadership style, and the principal's strategy.

\subsubsection{Documentation}

The documentation technique is used to strengthen and complete the data from the interviews. The source consists of various documents or records. documents used for reference are letters, diaries, photographs, speech scripts, education manuals. The documents used in this study are those related to the principal's leadership in building the quality of education.

\subsection{Data Analysis Technique}

This data analysis technique uses descriptive analysis techniques. The data obtained will be analyzed qualitatively and described in a descriptive form which aims to obtain data related to the leadership of the principal in building the quality of education. There are two stages of data analysis conducted by researchers in carrying out this research, these are analysis of individual site data and analysis of cross-site data.

\subsubsection{Analysis of Individual Site Data}

Analysis of individual site data was conducted by analyzing each research object, both in Senior High School 1 Pamekasan and Senior High School 3 Pamekasan. The steps in the analysis of individual site data in this study, according to [11], and [12], which consist of data condensation, data presentation, and drawing the conclusion.

\subsubsection{Analysis of Cross Site Data}

Cross-site data analysis is intended as a process for comparing findings obtained from the first and second cases. In addition, cross-site data analysis also aims to 
May-Jun 2020 /Available online: https://ijels.com/

integrate findings between sites. According to [13], the steps that can be taken in cross-site analysis include: (a) using an inductive-conceptualistic approach (b) the results are then used as a basis for compiling conceptual statements or cross-site propositions, (c) evaluating the suitability of the proposition with the facts being referred to, (d) reconstructing the proposition that has been found in accordance with the facts of each individual site, (e) repeating the cycle as long as it is needed. The process of cross-site data analysis is more clearly shown in Fig. 1.

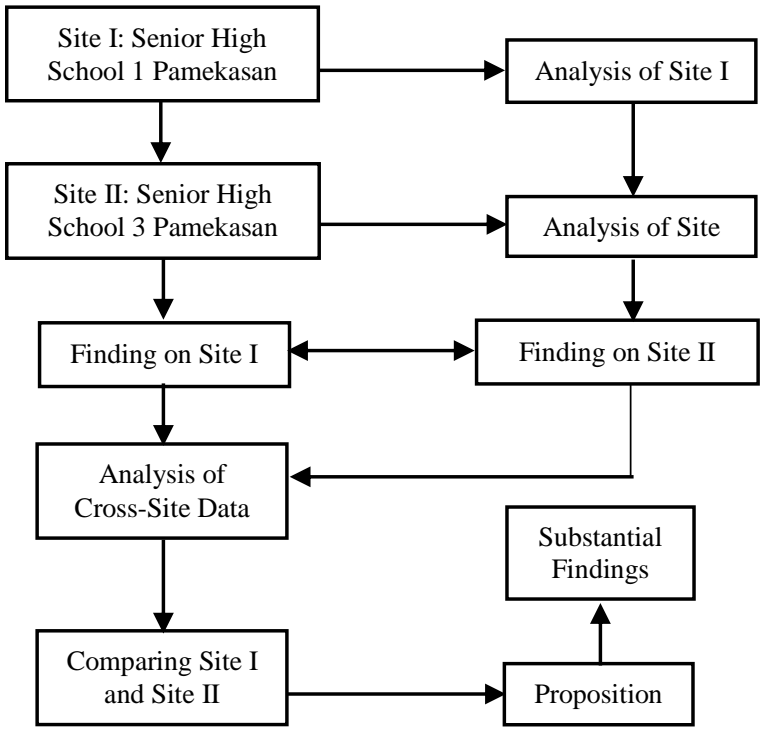

Fig. 1: Model of Cross-site Analysis

\section{RESULT AND DISCUSSION}

Based on the data that has been obtained with data collection techniques, the detailed results of the principal's leadership in building the quality of education in Senior High School 1 Pamekasan shown in Table 1 and Senior High School 3 Pamekasan in Table 2.

Table 1:Findings Matrix of Site I (Senior High School 1 Pamekasan)

\begin{tabular}{|l|l|l|}
\hline No. & \multicolumn{1}{|c|}{ Focus } & \multicolumn{1}{|c|}{ Summary of Result } \\
\hline 1. & $\begin{array}{l}\text { What is the } \\
\text { principal's } \\
\text { leadership } \\
\text { style in } \\
\text { building the } \\
\text { quality of } \\
\text { education? }\end{array}$ & $\begin{array}{l}\text { Principal leadership style that is } \\
\text { considered effective and applied by } \\
\text { the principal is a situational } \\
\text { leadership approach model. In its } \\
\text { implementation, the principal seeks } \\
\text { to recognize first the needs of } \\
\text { individuals or teams, then use the } \\
\text { best leadership style to respond } \\
\text { appropriately. }\end{array}$ \\
\hline
\end{tabular}

\begin{tabular}{|l|l|l|}
\hline 2. & $\begin{array}{l}\text { How is the } \\
\text { principal's } \\
\text { strategy in } \\
\text { building the } \\
\text { quality of } \\
\text { education }\end{array}$ & $\begin{array}{l}\text { The principal implemented the } \\
\text { integrated quality management } \\
\text { strategy, which in its implementation } \\
\text { carried out the maintenance of the } \\
\text { existing service system in the school } \\
\text { by involving all school communities }\end{array}$ \\
\hline 3. & $\begin{array}{l}\text { How is the } \\
\text { quality of } \\
\text { education } \\
\text { produced } \\
\text { by the } \\
\text { principal's } \\
\text { leadership } \\
\text { style }\end{array}$ & $\begin{array}{l}\text { The applied situational leadership } \\
\text { style produces some positive cultural } \\
\text { values in schools, namely; creating a } \\
\text { culture of collaboration and } \\
\text { communication, creating an inclusive } \\
\text { school environment, building a sense } \\
\text { of responsibility for all elements of } \\
\text { the school, increasing the motivation } \\
\text { of students to achieve goals, fostering } \\
\text { a sense of togetherness, creates a } \\
\text { conducive environment, and } \\
\text { strengthening organizational } \\
\text { commitment in improving the quality } \\
\text { of education in general. }\end{array}$ \\
\hline
\end{tabular}

Table 1:Findings Matrix of Site II (Senior High School 3 Pamekasan)

\begin{tabular}{|l|l|l|}
\hline No. & \multicolumn{1}{|c|}{ Focus } & \multicolumn{1}{|c|}{ Summary of Result } \\
\hline 1. & $\begin{array}{l}\text { What is the } \\
\text { principal's } \\
\text { leadership } \\
\text { style in } \\
\text { building } \\
\text { the quality } \\
\text { of } \\
\text { education? }\end{array}$ & $\begin{array}{l}\text { Leadership model which is } \\
\text { applied by the principal is } \\
\text { participatory leadership approach } \\
\text { model. The choice of leadership } \\
\text { model conducted by the school } \\
\text { principal is based on the state of the } \\
\text { situation and condition of the } \\
\text { school where he explained that the } \\
\text { teachers there were competent but } \\
\text { sometimes lacked enthusiasm and } \\
\text { motivation. }\end{array}$ \\
\hline 2. & $\begin{array}{l}\text { How is the } \\
\text { principal's } \\
\text { strategy in } \\
\text { building } \\
\text { the quality } \\
\text { of } \\
\text { education }\end{array}$ & $\begin{array}{l}\text { The principal implemented the } \\
\text { integrated quality management } \\
\text { strategy, namely Integrated Quality } \\
\text { Management In practice, the } \\
\text { principal builds a system by } \\
\text { regulating and managing each } \\
\text { element of the school so that they } \\
\text { can jointly pay attention to } \\
\text { improving the quality of education. }\end{array}$ \\
\hline
\end{tabular}


May-Jun 2020 /Available online: https://ijels.com/

\begin{tabular}{|l|l|l|}
\hline 3. & $\begin{array}{l}\text { How is the } \\
\text { quality of } \\
\text { education } \\
\text { produced } \\
\text { by the } \\
\text { principal's } \\
\text { leadership } \\
\text { style }\end{array}$ & $\begin{array}{l}\text { The results of the quality of } \\
\text { participatory leadership of the } \\
\text { principal is the formation of good } \\
\text { cultures in schools, including; } \\
\text { creating a conducive school } \\
\text { environment, fostering a sense of } \\
\text { responsibility for all elements of the } \\
\text { school, fostering the morale of } \\
\text { subordinates in this case teachers } \\
\text { and employees, fostering a sense of } \\
\text { togetherness, and strengthening } \\
\text { organizational commitment in } \\
\text { improving the quality of education } \\
\text { in general }\end{array}$ \\
\hline
\end{tabular}

Based on the data exposure of each site in Senior High School 1 Pamekasan and Senior High School 3 Pamekasan have similarities and differences at each focus of research. From the results of the analysis of each research site that has been studied and elaborated on the leadership of the principal in building the quality of education, the researcher could explain the finding of cross-site analysis as shown in Table 3.

Table 3: Finding Matrix of Cross-site

\begin{tabular}{|c|c|c|c|c|}
\hline $\begin{array}{l}\text { Research } \\
\text { Focus }\end{array}$ & Concept & Findings in Site I & Findings in Site 2 & Findings of Cross-site \\
\hline \multirow{3}{*}{$\begin{array}{l}\text { How is the } \\
\text { principal's } \\
\text { leadership } \\
\text { style in } \\
\text { building } \\
\text { the quality } \\
\text { of } \\
\text { education }\end{array}$} & Concept & $\begin{array}{ll}\text { 1. } & \text { Authoritarian leadership } \\
\text { 2. } & \text { Democratic leadership } \\
\text { 3. } & \text { Free leadership }\end{array}$ & $\begin{array}{l}\text { 1. Authoritarian leadership } \\
\text { 2. Democratic leadership } \\
\text { 3. Free leadership }\end{array}$ & $\begin{array}{ll}\text { Following the } \\
\text { principles of the } \\
\text { principal's needs }\end{array}$ \\
\hline & Orientation & \begin{tabular}{|lrr} 
Using & a & situational \\
leadership approach model
\end{tabular} & $\begin{array}{l}\text { Using a participatory leadership } \\
\text { approach model }\end{array}$ & $\begin{array}{l}\text { Use the leadership } \\
\text { style in accordance } \\
\text { with the potential of } \\
\text { existing resources }\end{array}$ \\
\hline & Implementation & $\begin{array}{l}\text { School principals are more } \\
\text { flexible in leading schools } \\
\text { by combining consultative, } \\
\text { instructive, delegative and } \\
\text { participatory leadership } \\
\text { models according to the } \\
\text { situation and conditions of } \\
\text { the school. }\end{array}$ & $\begin{array}{l}\text { Always involve subordinates in } \\
\text { the decision making process so } \\
\text { that the policies obtained are a } \\
\text { collective agreement because the } \\
\text { teacher is given the opportunity } \\
\text { to provide opinions, arguments } \\
\text { and creative options. }\end{array}$ & $\begin{array}{l}\text { Build capabilities } \\
\text { through the } \\
\text { performance of the } \\
\text { principal based on } \\
\text { effective leadership } \\
\text { styles }\end{array}$ \\
\hline $\begin{array}{l}\text { Principal's } \\
\text { strategy in } \\
\text { building } \\
\text { the quality } \\
\text { of } \\
\text { education }\end{array}$ & Step & $\begin{array}{l}\text { The principal of Senior } \\
\text { High School 1 Pamekasan } \\
\text { uses the Integrated Quality } \\
\text { Management strategy with } \\
\text { the aim of fulfilling and } \\
\text { developing ruman } \\
\text { resources, good } \\
\text { organizational management, } \\
\text { andratring } \\
\text { infrastructure / facilities and } \\
\text { infrastructure }\end{array}$ & $\begin{array}{l}\text { The principal of Senior High } \\
\text { School } 3 \text { Pamekasan uses the } \\
\text { Integrated Quality Management } \\
\text { (MMT) strategy with the aim of } \\
\text { fulfilling and developing human } \\
\text { resources, good organizational } \\
\text { management, and improving } \\
\text { infrastructure / facilities and } \\
\text { infrastructure }\end{array}$ & $\begin{array}{l}\text { Implement an } \\
\text { integrated quality } \\
\text { management strategy } \\
\text { by involving all } \\
\text { elements of the school } \\
\text { in building the quality } \\
\text { of education }\end{array}$ \\
\hline
\end{tabular}




\begin{tabular}{|c|c|c|c|c|}
\hline & Actualization & $\begin{array}{l}\text { 1. Strengthening character } \\
\text { education } \\
\text { 2. Good Organizational } \\
\text { Management as a } \\
\text { motivator facilitator } \\
\text { and visionary } \\
\text { 3. Improving the Quality } \\
\text { of Facilities and } \\
\text { Infrastructure }\end{array}$ & $\begin{array}{l}\text { 1. Continuous improvement of } \\
\text { the system by giving more } \\
\text { portions to superior classes } \\
\text { in learning } \\
\text { 2. System improvement related } \\
\text { to fulfilling the facilities for } \\
\text { developing talent and interest } \\
\text { through extracurricular } \\
\text { activities } \\
\text { 3. Create a short-term, medium- } \\
\text { term and a long-term quality } \\
\text { assurance program }\end{array}$ & $\begin{array}{l}\text { Improving the overall } \\
\text { education system by } \\
\text { involving all school } \\
\text { members }\end{array}$ \\
\hline & Strengthening & 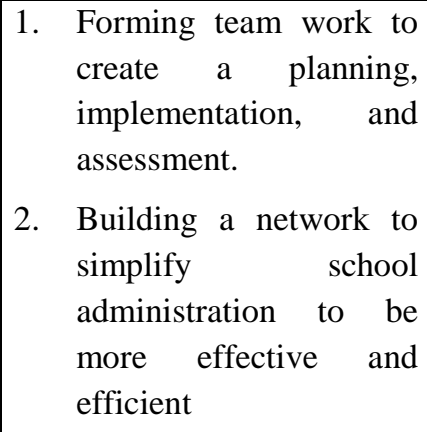 & $\begin{array}{l}\text { Building a network with the } \\
\text { world of work and universities, } \\
\text { where many alumni of the } \\
\text { school occupy some important } \\
\text { posts in the society such as the } \\
\text { police, army and civil servants } \\
\text { as well as the many alumni } \\
\text { accepted at several reputable } \\
\text { institutions }\end{array}$ & $\begin{array}{l}\text { Establish } \\
\text { relations with related } \\
\text { parties, both internal } \\
\text { and external }\end{array}$ \\
\hline \multirow[t]{2}{*}{$\begin{array}{l}\text { The quality } \\
\text { of } \\
\text { education } \\
\text { produced } \\
\text { by the } \\
\text { leadership } \\
\text { style of the } \\
\text { principal }\end{array}$} & Concrete & $\begin{array}{l}\text { produce some positive } \\
\text { cultural values in the school, } \\
\text { including: } \\
\text { 1. Create the culture of } \\
\text { collaboration and } \\
\text { communication } \\
\text { 2. Create the inclusive } \\
\text { school environment } \\
\text { 3. Build the sense of } \\
\text { responsibility of all } \\
\text { elements of the school }\end{array}$ & $\begin{array}{l}\text { Some positive implications } \\
\text { resulting from the leadership } \\
\text { style of the principal are: } \\
\text { 1. Create a conducive school } \\
\text { environment. } \\
\text { 2. Foster a sense of } \\
\text { responsibility for all } \\
\text { elements of the school. } \\
\text { 3. Bring up the morale of the } \\
\text { subordinates. }\end{array}$ & $\begin{array}{l}\text { Able to create a } \\
\text { productive and quality } \\
\text { school culture }\end{array}$ \\
\hline & Abstract & $\begin{array}{l}\text { Strengthen organizational } \\
\text { commitment in improving } \\
\text { the quality of education }\end{array}$ & $\begin{array}{l}\text { Strengthen organizational } \\
\text { commitment in improving the } \\
\text { quality of education }\end{array}$ & $\begin{array}{l}\text { Able to build } \\
\text { organizational } \\
\text { mentality }\end{array}$ \\
\hline
\end{tabular}

Based on data collection, research findings, data analysis, and the focus of research in this study, the researcher can determine and propose several propositions as follows:

- Principal's Leadership Style in Building Quality

\section{Education}

Proposition1. Building the quality of education will succeed if it is built on the principle of the needs of the principal.
Proposition 2. Building the quality of education will be successful if the principal uses a leadership style that is tailored to the potential of existing resources in the school.

Proposition 3. Building the quality of education will succeed if the principal can build his abilities through the performance of the principal based on an effective leadership style.

- School Strategies in Building the Quality of School Education 
May-Jun 2020 /Available online: https://ijels.com/

Proposition 1. Building the quality of education will succeed if the school implements the Integrated Quality Management strategy by involving all elements of the school.

Proposition 2. Building the quality of education will succeed if it is actualized by improving the overall education system by involving all school members.

Proposition 3. Building the quality of education will succeed if the school establishes good relations with internal and external parties of the school.

- Quality Produced by the Principal's Leadership Style

Proposition1. Building the quality of education will be successful if it is able to improve the academic and non academic achievements of the academic community.

Proposition2. Building the quality of education will be successful if it is able to create a productive and quality school culture.

Proposition3. Building the quality of education will be successful if it is able to strengthen the organizational commitment and mentality of every school citizen.

\section{CONCLUSION}

An effective principal's leadership style must be adapted to the potential of existing resources in the school. The consequence that the leadership approach model must be in accordance with the state of available resources in the school. Its implementation using the leadership model carried out by the principal of Senior High School 1 Pamekasan emphasizes assignments and relationships with teachers and employees, depending on the need to get success from the work done. In leading the Senior High School 3 Pamekasan, the school principal modeled a participatory leadership approach. Therefore, the principal's leadership style should follow the principle of the needs of the principal itself. The principal of Senior High School 1 Pamekasan and Senior High School 3 Pamekasan carry out an Integrated Quality Management strategy. To actualize the quality of education in the school, the principal conducts an overall system improvement by involving all elements of school. In order to ensure good quality education, schools must strengthen in the form of team work and network formation in order to accelerate the pace of school development. A conclusion section must be included and should indicate clearly the advantages, limitations, and possible applications of the paper. Although a conclusion may review the main points of the paper, do not replicate the abstract as the conclusion. A conclusion might elaborate on the importance of the work or suggest applications and extensions. The results of this study can contribute to the development of science in the field of education management especially in the role of the principal in building the quality of education.

\section{REFERENCES}

[1] Todorut, A. V. (2013). The need of total quality management in higher education. Social and Behavioral Sciences 83, 1105-1110. doi:10.1016/j.sbspro.2013.06.207

[2] Ali, M. \& Shastri, R. K. (2010). Implementation of Total Quality Management in Higher Education. Asian Journal of Business Management, 2 (1), 9-16

[3] Karahan, M. \& Mete, M. (2014) Examination of total quality management practices in higher education in the context of quality sufficiency. Social and behavioral science 109, 12921297. doi:10.1016/j.sbspro.2013.12.627

[4] Goetsch, D. L. \& Davis, S. B. (2000) Quality Management. New Jersey, Prentice Hall

[5] Bendermacher, G. W. G., oude Egbrink, M. G. A., Wolfhagen, I. H. A. P., Dolmans, D. H. J. M. (2017) Unravelling quality culture in higher education: a realist review. Higher Education , 73, 39-60

[6] Polatcan M. \& Titrek O. (2014) The relationship between leadership behaviors of school principals and their organizational cynicism attitudes. Social and behavioral sciences, 141, 1291. doi:10.1016/j.sbspro.2014.05.222

[7] Murphy, J., Smylie, M., Mayrowetz, D., \& Louis, K. S. (2009). The role of the principal in fostering the development of distributed leadership. School Leadership and Management, 29(2), 181-214.

[8] Mulford, B. \& Silins, H. (2003). Leadership for organizational learning and improved student outcomes-what do we know? Cambridge Journal of Education 33(2), 175195.

[9] Mintzberg, H. (2010) Developing Leaders? Developign Countries?. Oxford Leadership Journal, 1 (2), 1-10

[10] Top, S., Öge, E., Atan, O. Gümüs, S. (2015) Investigation relational levels of intensity between paternalistic and servant leadership styles and national culture, organizational commitment and subordinate response or reactions to the leader style. Social and Behavioral Sciences, 181, 12-22. doi: 10.1016/j.sbspro.2015.04.861

[11] Miles, M. B. \& Huberman A. M. (1994) An Expanded Sourcebook: Qualitative Data Analysis. London: Sage Publications.

[12] Denzin, N. K., \& Lincoln, Y. S. (2005) The Sage Handbook of Qualitative Research, Third Edition, Sage, Thousand Oaks.

[13] Moleong, L.J. (2001). Metodologi Penelitian Kwalitatif. Bandung: Remaja Rosdakarya 